\title{
Genotypes diversity of env gene of Bovine leukemia virus in Western Siberia
}

\author{
Natalia Blazhko ${ }^{1} \mathbb{D}$, Sultan Vyshegurov ${ }^{1} \mathbb{D}$, Alexander Donchenko ${ }^{2} \mathbb{D}$, Kirill Shatokhin ${ }^{*^{*}} \mathbb{D}$, Valeria Ryabinina ${ }^{1} \mathbb{D}$, \\ Kirill Plotnikov ${ }^{1}$ (D), Alevtina Khodakova ${ }^{1}$ (D) and Sergey Pashkovskiy ${ }^{1}$ (D)
}

From 11th International Young Scientists School "Systems Biology and Bioinformatics" - SBB-2019

Novosibirsk, Russia. 24-28 June 2019

\begin{abstract}
Background: This study describes the biodiversity and properties of Bovine leukemia virus in Western Siberia. This paper explores the effect of different genotypes of the env gene of the cattle leukemia virus on hematological parameters of infected animals. The researchers focused on exploring the polymorphism of the env gene and, in

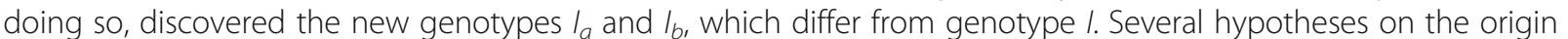
of the different genotypes in Siberia are discussed.

Results: We obtained varying length of the restriction fragments for genotypes / Additionally using restrictase Hae III were received fragments was named genotype $I_{a}$, and genotype $I_{b}$. There are $2.57 \pm 0.55 \%$ (20 out of 779 ) samples of genotype $I_{b}$ which does not differ significantly from $1 \%\left(X^{2}=2.46\right)$. Other genotypes were observed in the cattle of Siberia as wild type genotypes (their frequency varied from 17.84 to $32.73 \%$ ). The maximum viral load was observed in animals with the II and IV viral genotypes (1000-1400 viral particles per 1000 healthy cells), and the minimum viral load was observed animals with genotype $I_{b}$ (from 700 to 900 viral particles per 1000 healthy cells).

Conclusions: The probability of the direct introduction of genotype // from South America to Siberia is extremely small and it is more likely that the strain originated independently in an autonomous population with its distribution also occurring independently. A new variety of genotype $I\left(I_{b}\right)$ was found, which can be both a neoplasm and a relict strain.
\end{abstract}

Keywords: Bovine leukemia virus, Cattle, Env gene, Genotypes, Agriculture

\section{Background}

Viruses are the most variable form of life, and $B L V$ is not an exception. The origin of new strains is a continuous process [1-4]. Monitoring the origin of new virus mutations is of great importance for veterinary and animal husbandry, as every new strain may have unique features of interaction with the host organism. Accordingly, every new strain of the virus can be cause of completely

\footnotetext{
* Correspondence: true genetic@mail.ru

'Laboratory of Enzyme Analysis and DNA Technologies, Novosibirsk State Agricultural University, Novosibirsk, Russia

Full list of author information is available at the end of the article
}

another symptoms of the disease [5]. That's why, the monitoring of the spread and emergence of virus strains is relevant in every separated geographical region.

One of the most common and dangerous diseases of cattle is leukemia caused by Bovine leukemia virus $(B L V)$, which belongs to the family Retroviridae [6, 7]. One of its features is a high proportion of latent virus carriers (70-90\%) and low detestability of clinical symptoms by hematological methods, which complicates measures to identify sick animals and prevent the further spread of the disease [8-10]. BLV it is a virus transmitted by direct contact between animals. The transmitted

(c) The Author(s). 2020 Open Access This article is licensed under a Creative Commons Attribution 4.0 International License, which permits use, sharing, adaptation, distribution and reproduction in any medium or format, as long as you give appropriate credit to the original author(s) and the source, provide a link to the Creative Commons licence, and indicate if changes were made. The images or other third party material in this article are included in the article's Creative Commons licence, unless indicated otherwise in a credit line to the material. If material is not included in the article's Creative Commons licence and your intended use is not permitted by statutory regulation or exceeds the permitted use, you will need to obtain permission directly from the copyright holder. To view a copy of this licence, visit http://creativecommons.org/licenses/by/4.0/. The Creative Commons Public Domain Dedication waiver (http://creativecommons.org/publicdomain/zero/1.0/) applies to the data made available in this article, unless otherwise stated in a credit line to the data. 
$B L V$ from cattle to humans is possible but clinical symptoms in Homo sapiens have been registered in singular cases [11].

The probable reason for this is the tendency of Retroviridae representatives to embed into the carrier genome $[4,12]$. Therefore, it is important for viruses to have such a protein composition of the capsid, so as not to be interpreted by the immune system of the carrier as a danger. In $B L V$, capsid proteins are encoded by env gene. The env gene is located between the pol gene and the 3'LRT-area; it is $1547 \mathrm{bp}$ in length (from nucleotides 4826 to 6373 , numbering from the $B L V$ env sequence of the isolate FLK- $B L V$, GenBank accession number EF600696). 4615-6160 bp). This gene encodes the glycoprotein viral membrane of $g p 51$ and the transmembrane protein $g p 30$. The proteins - $g p 51(\mathrm{SU})$ and $g p 30(\mathrm{TM})$ are glycolized [13-16]. Protein $g p 30$ contributes to the contact between viral particles and B- and T- cells and its properties affect the ability of the sheep immune system to recognize the viral particles $[17,18]$. This protein can define the ability of $B L V$ to affect the immune system cells of a carrier [19]. The $g p 51$ protein reacts with monoclonal cattle antibodies and determines the degree of $B L V$ virulence [20]. Therefore, qualitative changes in the $g p 30$ and $g p 51$ proteins that are caused by gene mutations may become the factors that affect the intensity of the immune response. So for specialists involved in coevolution of $B L V$ and cattle, it is of great interest to study the relationship between individual mutations and genotypes of the virus with the phenotypic manifestation of leukemia.

The $B L V$ genome includes four structural genes (env, pro, gag, and pol), of which env is the most suitable for detecting the pathogen by PCR analysis [21-23]. There are 10 genotypes of the env gene in the world [24, 25] and each creates slight differences in the biological properties of the virus. This research aims to definethe virulent properties of the $B L V$ genotypes that have been discovered in Western Siberia as well as the newly discovered forms of the genotypes on the env gene.

\section{Results}

PCR-RFLP analysis of the env gene detected 5 genotypes that differed on the lengths of fragment restriction. This restriction is caused by restrictases HaeIII and BstYI (Table 1). The effect of the restriction endonuclease HaeIII differed from the supposed effect. The fragment restriction lengths of $316,27,95$, and 5 bp were expected to show up on the electrophorogram as they are considered to be the standard products of genotype $I$ restriction [26]. However, additional fragments of restriction were found as genotypes $I_{a}$ and $I_{b}$ (Table 1, Fig. 1).

Restriction fragments (length $27 \mathrm{bp}$ ) are considered to be a common trait for all three genotypes of the family $I$.
Table 1 Scheme of genotypes formed by restrictases Haelll and BstYl

\begin{tabular}{|c|c|c|}
\hline \multirow[t]{2}{*}{ Genotype } & \multicolumn{2}{|l|}{ Restrictase } \\
\hline & Hae III & BstYl \\
\hline I & $316-27-95-5$ & - \\
\hline $\mathrm{l}_{\mathrm{a}}$ & $31-285-27-95-5$ & - \\
\hline $\mathrm{l}_{\mathrm{b}}$ & $31-85-200-27-100$ & - \\
\hline$\|$ & - & $529-322-143$ \\
\hline IV & - & $672-322$ \\
\hline
\end{tabular}

The table highlights the fragment restrictions with length (b.p)

The common factors for genotypes $I$ and $I_{a}$ are fragments of 95 and $5 \mathrm{bp}$ (Fig. 1). Genotype $I_{b}$ differs from related genetic elements as it combines these fragments into a single one (100 bp length). The common restriction fragments of genotypes $I_{a}$ and $I$ reveal a short sequence (31 bp), whereas the long fragment that is typical for genotype $I_{a}(285 \mathrm{bp})$, is represented by two separate factions (85 and 200 bp) (Fig. 1).

The prevalence of the previously discovered and explored genotypes varied from 17.84 to $32.73 \%$ with the exception of the $I_{b}$ genotype (Fig. 2). The number of samples with genotype $I_{a}$ was $20.95 \pm 1.46 \%$ (171 out of $779)$, which differed significantly $\left(x^{2}=398 ; P<0,001\right)$ from the statistical and methodological error and is equal to $1 \%$ [2]. The number of samples with genotype $I_{b}$ was $2.57 \pm 0.55 \%$ (20 of 779 ) and didn't differ significantly from $1 \%\left(x^{2}=2.46\right)$. Therefore, of the two new genetic formations that were observed in the cattle of $\mathrm{Si}$ beria, only the $I_{a}$ genotype is thought to occur normally (not mutant) in population frequency.

The highest number of leukocytes was observed in the blood of animals infected with the $B L V$ of the genotype $I$. The hematological status was different in sick animals $(\mathrm{P}<0.01: \mathrm{P}<0.001)$ and the total sample $(\mathrm{P}<0.001)$. The carriers of the $I_{b}$ genotype were seen as the only exceptions; the difference in the number of leukocytes in the animals of the $I$ genotype was not reliable (Table 1 ). The differences in the hematological status of the carriers of genotypes $I_{a}, I I$, and $I V$ were not significant or they were of a low reliability $(\mathrm{P}<0.05)$.

The carriers of the cattle leukemia virus $I, I_{a}, I I$, and $I V$ genotypes were observed among animals that were sick, healthy, and those that were suspected of having leukemia. There was a heterogeneous relationship among the animals of different hematological statuses and animals infected by different virus genotypes (Table 2).

The highest number of lymphocytes was observed in the blood of genotype $I$ carriers, while the lowest number of lymphocytes was found in the animals with genotype II (Table 2). The similarity of the qualitative blood parameters of the cattle infected with $B L V$ in different 


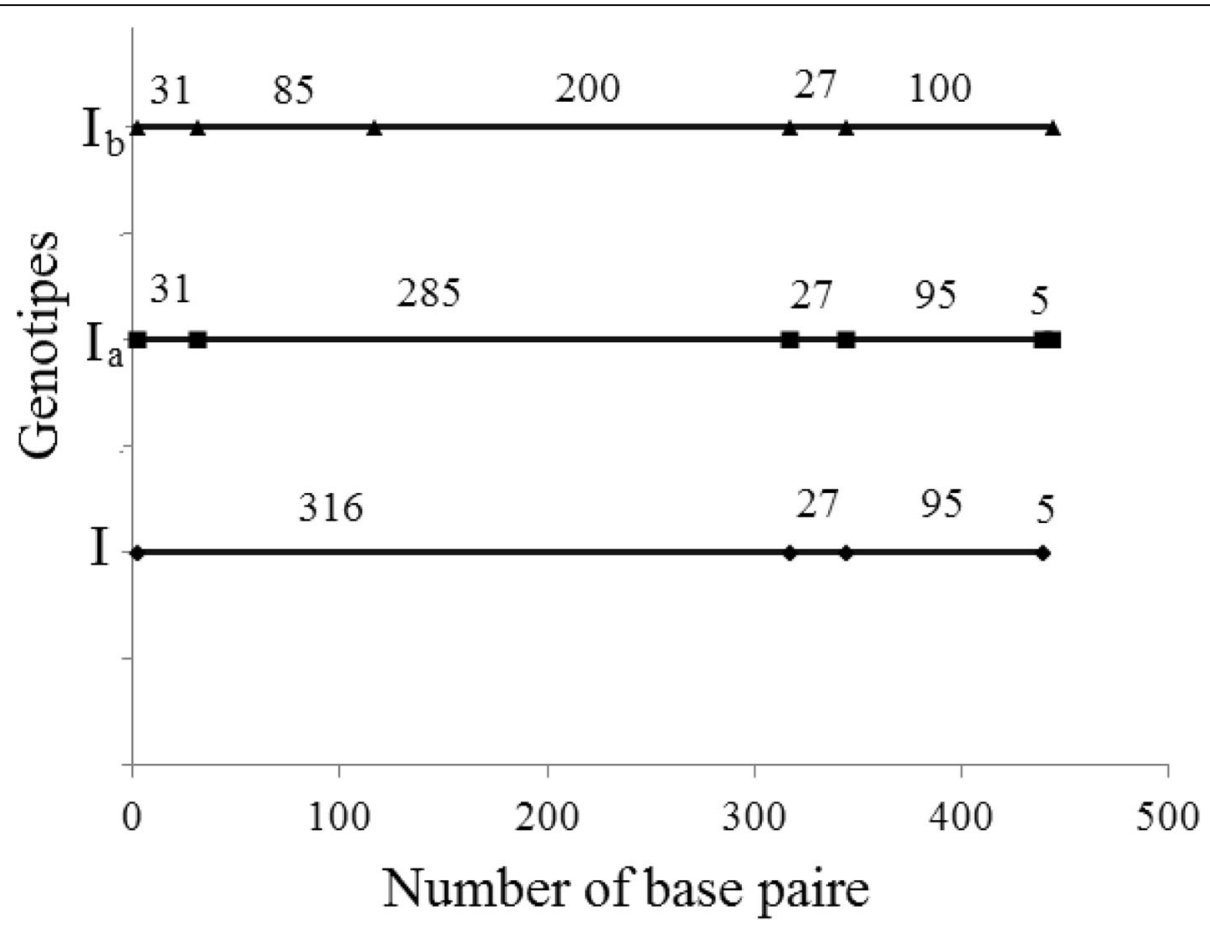

Fig. 1 Schemeof Haell restriction with formation of genotypes

genotypes of the env gene, expressed through Wilks' lambda statistic (0.82285), can be considered with some to be sufficiently high, but not identical.

The investigation into the bovine viral status had unexpected result. The typical sequence of viral load distribution for genotypes on the LRT-area [27] (sick $>$ suspected > healthy) is not clearly shown in the present experiment (Fig. 3). Observed a non-typical relationship between the physiological status and viral status in the animals infected with genotype $I$. The maximum number of viral particles was observed in the blood of healthy animals, slightly lower in suspected animals, and minimally in animals with hematolytic leukemia (Fig. 3).

\section{Discussion}

The current research does not prove that the higher the viral load, the higher the immune response of the

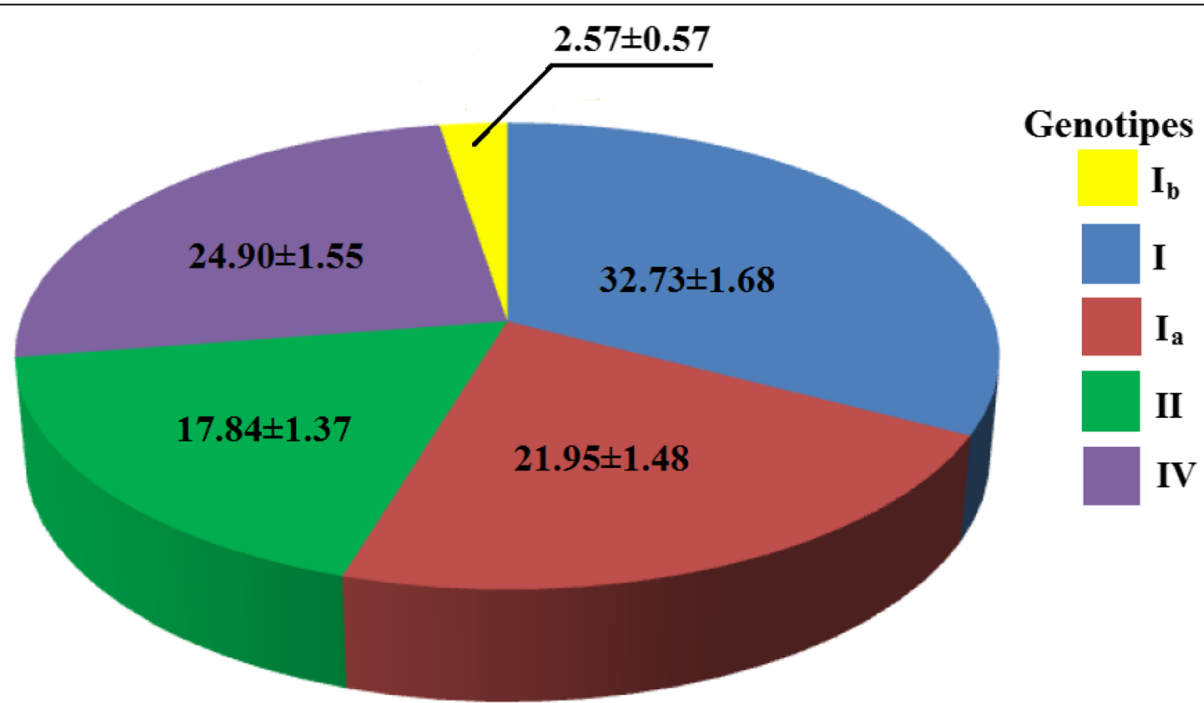

Fig. 2 Frequency of env gene genotypes (\%) in Western Siberia 
Table 2 Cytometric and morphological parameters of blood of animals-carriers of different genotypes of BLV

\begin{tabular}{|c|c|c|c|c|c|c|c|c|c|c|}
\hline \multirow[t]{2}{*}{ env } & \multirow{2}{*}{$\begin{array}{l}\text { Hematological } \\
\text { status }\end{array}$} & \multicolumn{4}{|c|}{ WBC, $10^{9} / \mathrm{l}$} & \multicolumn{4}{|c|}{ lymf, $10^{9} / 1$} & \multirow[t]{2}{*}{$n$} \\
\hline & & $\bar{x}$ & $S_{\bar{x}}$ & $-5 \%$ & $+5 \%$ & $\bar{x}$ & $S_{\bar{x}}$ & $-5 \%$ & $+5 \%$ & \\
\hline \multirow[t]{4}{*}{$\overline{1}$} & suspected & 12.30 & 0.132 & 12.04 & 12.56 & 5.60 & 0.104 & 5.39 & 5.81 & 210 \\
\hline & sick & 24.18 & 0.452 & 23.29 & 25.07 & 13.65 & 0.357 & 12.94 & 14.35 & 18 \\
\hline & healthy & 4.95 & 0.369 & 4.22 & 5.68 & 2.45 & 0.292 & 1.88 & 3.03 & 27 \\
\hline & On average & 12.36 & 0.180 & 12.01 & 12.71 & 5.83 & 0.140 & 5.55 & 6.12 & 255 \\
\hline \multirow[t]{4}{*}{$l_{a}$} & suspected & 11.26 & 0.256 & 10.76 & 11.76 & 5.11 & 0.202 & 4.72 & 5.51 & 56 \\
\hline & sick & 19.82 & 0.429 & 18.98 & 20.66 & 12.38 & 0.339 & 11.71 & 13.04 & 20 \\
\hline & healthy & 7.06 & 0.197 & 6.67 & 7.44 & 3.08 & 0.155 & 2.77 & 3.39 & 95 \\
\hline & On average & 9.93 & 0.240 & 9.44 & 10.40 & 4.83 & 0.190 & 4.45 & 5.21 & 171 \\
\hline \multirow[t]{4}{*}{$\|$} & suspected & 9.73 & 0.195 & 9.35 & 10.11 & 4.09 & 0.154 & 3.79 & 4.40 & 97 \\
\hline & sick & 17.40 & 1.109 & 15.22 & 19.57 & 9.36 & 0.876 & 7.64 & 11.08 & 3 \\
\hline & healthy & 6.81 & 0.307 & 6.21 & 7.42 & 3.04 & 0.243 & 2.57 & 3.52 & 39 \\
\hline & On average & 9.08 & 0.246 & 8.60 & 9.56 & 3.91 & 0.195 & 3.53 & 4.30 & 139 \\
\hline \multirow[t]{4}{*}{ IV } & suspected & 11.70 & 0.233 & 11.24 & 12.16 & 5.44 & 0.184 & 5.08 & 5.80 & 68 \\
\hline & sick & 17.25 & 0.960 & 15.36 & 19.13 & 10.50 & 0.759 & 9.00 & 11.99 & 4 \\
\hline & healthy & 8.36 & 0.173 & 8.02 & 8.70 & 3.57 & 0.137 & 3.30 & 3.84 & 122 \\
\hline & On average & 9.71 & 0.210 & 9.30 & 10.13 & 4.37 & 0.170 & 4.04 & 4.70 & 194 \\
\hline $\mathrm{I}_{\mathrm{b}}$ & suspected & 11.99 & 0.429 & 11.14 & 12.83 & 5.68 & 0.339 & 5.018 & 6.35 & 20 \\
\hline
\end{tabular}

Wilks' lambda statistic $=0,82,285, \mathrm{~F}(12,1530)=13,056, p<0,001$

WBC - number of white blood cells; lymf - number of lymphocytes $\bar{X}$ - the arithmetic average; $S_{\bar{X}}$ - error of the arithmetic average; -5 and $+5 \%$ are denoted the corresponding deviation of the attribute in the greater and lesser direction relative to the arithmetic mean; $n-$ number of animals

leucocytes, despite the earlier results that showed that the genotypes of the LRT area affect the type of cattle leukosis [27]. The research shows that the highest number of leukocytes was observed in the blood of the cattle infected with the virus of I genotype (Table 1); the highest viral load was observed in the animals infected with $B L V$ of $I I$-and $I V$ genotypes (Fig. 3.).
The research results are unique due to the high diversity of the discovered virus genotypes (4 genotypes of the standard frequency and 1 genotype of the frequency indistinguishable from 1\%) (Table 2, Fig. 2). Early research detected one or two $B L V$ genotypes of the env gene inone population of cattle [24, 28]. The observed diversity of the virus may be caused by the massive

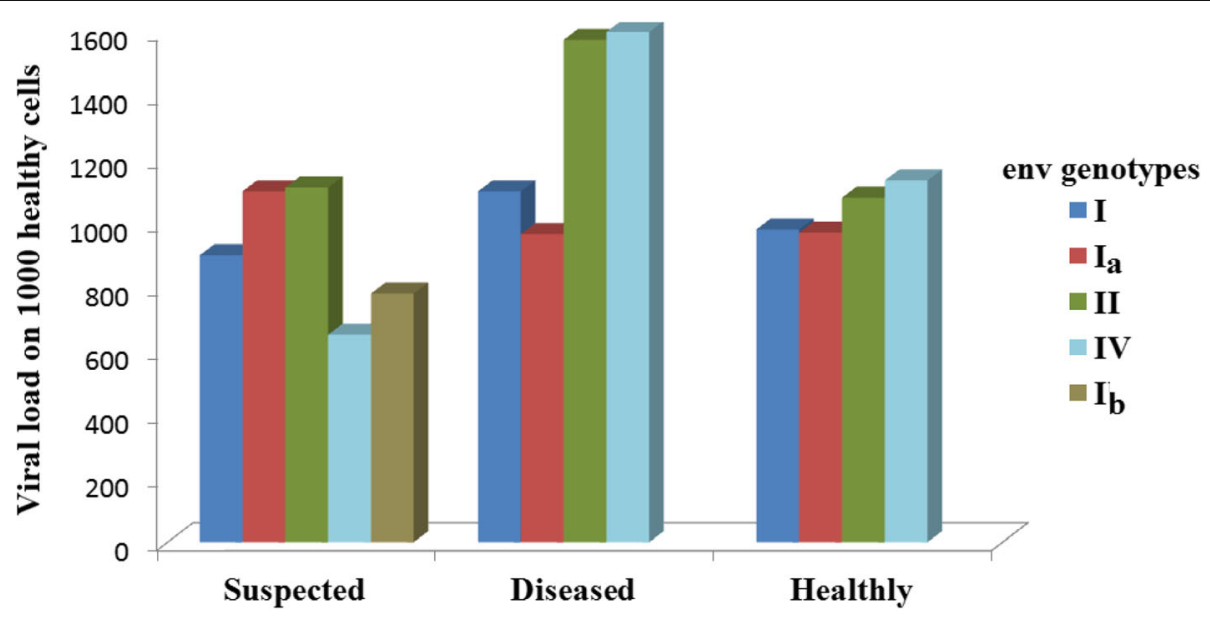

Fig. 3 Distribution if viral load at different stages of infection progress in relation to heterogeneity of env gene $B L V($ Wilks' $=0,66,912, F=28,406$, $p<0.001$; confidence intervals-95\%) 
import of cattle to Siberia from other regions, particularly from abroad.

Interestingly, genotypes $I$ and $I V$ and their subtypes were found in $B L V$ isolated from the biological material of cattle that were bred in different countries. Genotype $I$ was found in the cattle from Japan, the United States, Australia, Germany, Korea, Iran, Brazil, Colombia, and the Dominican Republic [24, 29-34]. Genotype $I V$ was observed in the cattle from Brazil, Belgium, Poland, Ukraine, and France. In Russia, and particularly in Siberia, only genotype $I V B L V$ by the env gene was observed early [29, 33]. The cattle and sperm from Europe, the US, and Canada were delivered to Siberiain order to improve local livestock productivity $[35,36]$, the presence of the $B L V$ genotypes $I$ and $I V$ in the explored sample is logically explained.

Interestingly the presence of the genotype II, peculiar only to South American cattle populations, had an frequency of $17.84 \%$ in the blood samples (Fig. 2). Cattle delivery from South American countries, where genotype II is widespread, to Siberia is not observed in the scientific literature. The cattle from South America have similar dairy productions to Russian cattle [37, 38]. The period of delivery and the different climate conditions between Siberia and South America assume lack of breeding and economic efficiency of black and white cattle when considering their delivery from South America to Siberia. Therefore, the introduction of genotype II $B L V$ seems highly doubtful.

Phylogenetically, genotype $I I B L V$ is a separate complex that is distant from genotypes $I$ and $I V$ [39]. The research on isolated laboratory strains of E. coli [40] and red salmon inhabiting the rivers and lakes of Alaska [41] showed the independent directions of mutagenesis in the isolated populations. The model of allopatric speciation is based on geographical isolations [42] that helps divergence of morphogenetic characteristics of the strains, breeds, or populations [3, 43, 44]. Therefore, the possibility of an independent formation of the Siberian and South American $B L V$ genotype II by convergent processes accepted as unlikely. It may be that genotype II $B L V$ originated in a certain, presumably European or North American, cattle population and was then further introduced in the another regions. It is in Europe and North America that are the main suppliers of bull semen with a maternal productivity of $15,000 \mathrm{~kg}$ of milk per 305 days of lactation to other regions of the world [37]. Therefore, the assumption of the origin of the II genotype in the European or North American cattle population looks quite reasonable. Subsequently, probably, there was its independent introduction to Siberia and to South America together with importation of animals or a semen of bulls. However, this hypothesis, despite its logic, remains only a working version that requires additional experimental verification.
The map of restriction fragments (Fig. 1) defines the line of mutations caused by genotype $I$ to genotype $I_{b}$ (Fig. 4a). This statement is arguable based on the controversial idea that if something had not been discovered before, then it did not exist. Our previous article and other papers [27, 45, 46] have highlighted the evolutionary advantage of more viral strains over less viral ones. Changes, as a rule, mostly aim at improving the functional properties of an object and its complex structural organization [3, 47]. Therefore, the general evolutionary vector should aim at increasing viral capacity it is supported by the rapid synthesis of viral particles and contributes to the evolutionary advantage of the strain as an intra specific generation. Analyzing the maximum number of leukocytes and the viral load, the observed genotype $I_{b}$ as the least virulent and prevalent, followed by genotype $I_{a}$. The virus with genotype $I$ (Table 2, Fig. 3) caused the highest immune response.

Thus, the second hypothesis can be put forward for the chronology of $B L V$ genotypes originating from the env gene, where genotype $I_{b}$ can be considered as the initial form, and then, due to the accumulation of mutations, the strain $I_{a}$ emerged, and the last and most progressive form is the carrier particles of genotype $I$ (Fig. 4b).

Considering the analysis of restriction fragments (Fig. 1), there is third hypothesis which states that genotype $I_{a}$ is the ancestral one and the mutations that formed genotypes $I$ and $I_{b}$ were accumulated independently (Fig. 4c). This model seems to be the least attractive as it admits the appearance and consolidation of genotype $I_{b}$ with a frequency indistinguishable from the mutant one, with the lower

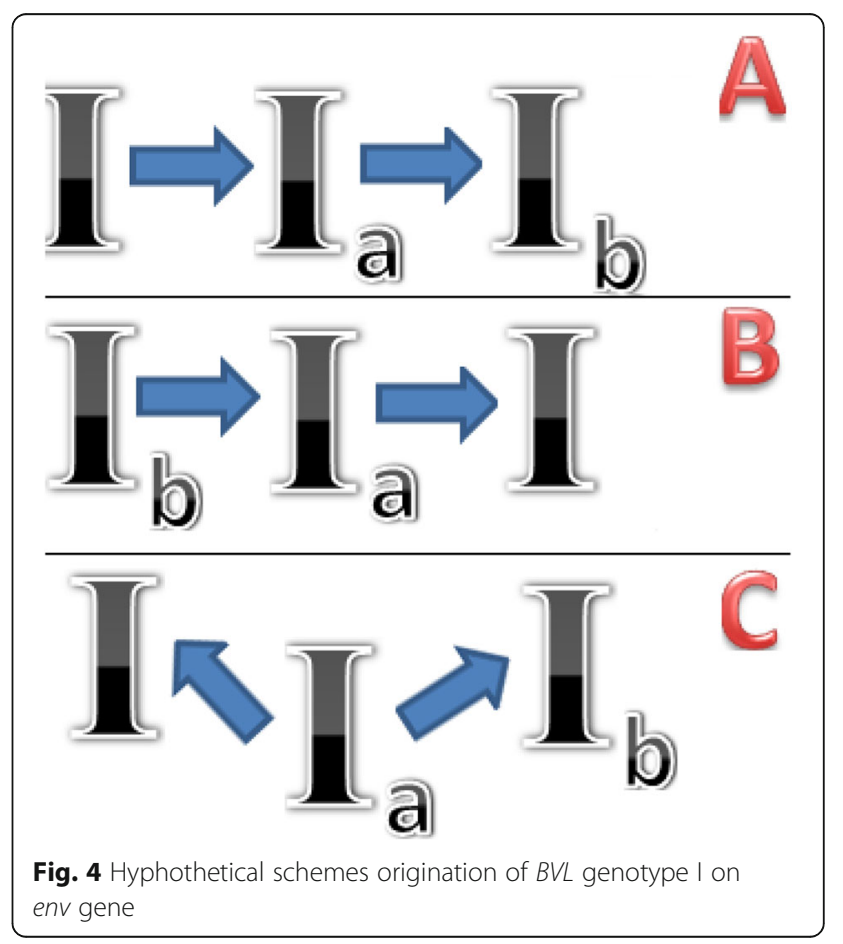


number of viral particles than that of genotype $I_{a}$, and lower rate of their synthesis. This means a lower reproduction of a virus'sown copies and an evolutionary unattractiveness to this new formation.

Two of the three mentioned hypotheses make the case that genotypes $I_{a}$ and $I_{b}$ are not new growths that emerged in Western Siberia as a result of mutagenesis. They are relict forms of $B L V$, preserved in the cattle and displaced in other places by progressive strains.

\section{Conclusions}

The research discovered of5 $B L V$ genotypes in the env gene, where genotype $I_{b}$ was observed with a frequency $(2.57 \pm 0.57 \%)$ indistinguishable from that of the mutant genotype (1\%). Genotypes $I, I_{a}, I I, I V$ were found to have a frequency of 17.84 to $32.73 \%$. The highest number of leukocytes was observed in the blood of animals infected with the $B L V I$ genotype. Hematological status differed in respect to sick animals $(\mathrm{P}<0,001)$ and the sample as a whole $(\mathrm{P}<0,001)$. The maximum viral load was observed in the carriers of genotypes $I I$ and $I V$ (1000-1400 viral particles per 1000 healthy cells). The number of viral particles in the family $I$ genotypes vary from 700 to 900 . For the first time, the paper describes genotypes $I_{a}$ and $I_{b}$. Three hypotheses were suggested that try to explain the stages in the origination of genotype $I$. According to one of the hypotheses, genotypes $I_{a}$ and $I_{b}$ are new growths that originated in Western Siberia due to mutagenesis. Two other theories suggest that the explored genotypes are relict forms of $B L V$ that have been displaced in the cattle by more progressive strains.

\section{Methods}

Samples of whole blood were taken from black and -white Holstein cows $(n=779)$ located in the Novosibirsk region in Russia. The blood samples were obtained in May 2019 from the sub clavian vein using sterile catheters with EDTA added as an anticoagulant. Cytofluorometric and morphological parameters of the blood were determined by means of the RSE-90 Vet automatic veterinary hematological analyzer.

The total DNA was isolated by DNA-Sorb-B (Central Research Institute of Epidemiology, Russia) in order to conduct PCR analysis. The screening tests for observation of $B L V$ in the blood samples were conducted by AmpliSens $^{\ominus}$ (Central Research Institute of Epidemiology, Russia). The authors explored the env gene sequence by means of PCR-RPF analysis ( $g p 51$ fragment of env gene) according to the practice of the National Veterinary Institute (Poland, Pulava). Amplification was accomplished using the nest method in two stages with the use of 3 primers. The number of cycles, their temperature, and time parameters were set in agreement with the methodology of the National Veterinary Institute (Table 3). As the control
Table 3 Temperature profile of PCR

\begin{tabular}{lll}
\hline Number of cycles & Temperature, ${ }^{\circ} \mathrm{C}$ & Period of time \\
\hline 1 & 95 & $3 \mathrm{~min}$ \\
34 & 95 & $30 \mathrm{~s}$ \\
& 62 & $30 \mathrm{~s}$ \\
& 72 & $2 \mathrm{~min}$ \\
1 & 72 & $10 \mathrm{~min}$ \\
Storage & 4 & $<12 \mathrm{~h}$ \\
\hline
\end{tabular}

strain was used FLK isolate The FLK strain (GenBank inventory number EF600696).

The calculation of the number of components necessary for a reaction in line with the recommended number of samples was obtained according to the formula (1):

$$
M=m \times n+3+1
$$

Where, $m$ is the amount of reaction mixture per a sample, $n$ is the number of samples for virus tests, 3 is the number of controls in the reaction $(\mathrm{IC}=$ internal control for $\mathrm{PCR}, \mathrm{NC}=$ negative control, $\mathrm{PC}=$ positive control), 1 is the safety amount of reaction mixture equal to the reaction mixture per a sample. FLK $B L V$ was applied as the positive control and a DNA buffer was used as the negative control. Table 4 illustrates the sufficient number of components for each reaction.

Primers from Table 5 were produced by an automated synthesizer of oligonucleotides that was purchased from the "SibEnzyme" (Novosibirsk, Russia). The accuracy of the primers was defined by the HPLC method and its accuracy was at least $95 \%$.

The products of amplification were analyzed by means of fragment restriction acceleration that was caused by the horizontal electrophoresis method in agarose gel. Samples suspected of short fragments were additionally detected by vertical electrophoresis in polyamide acrylic gel [48]. The restriction was realized by the enzymes

Table 4 Composition of reaction mixture

\begin{tabular}{lll}
\hline Mixture components & \multicolumn{2}{l}{ Necessary amount, $\mathrm{mcl}$} \\
\cline { 2 - 3 } & Reaction1 & Reaction2 \\
\hline 10xof optimized DNA-buffer & 5.0 & 5.0 \\
$10 \mathrm{mM} \mathrm{MgCl} 2$ & 1.0 & 1.0 \\
$10 \mathrm{mM}$ dNTP & 1.0 & 1.0 \\
$10 \mathrm{mM}$ primerAP (direct) & 1.0 & 1.0 \\
$10 \mathrm{mM}$ primerZM2 (reverse) & 1.0 & 1.0 \\
$2 \mathrm{U} / \mu \mathrm{LTAGpol}$ & 1.0 & 1.0 \\
Water, ml & 13.0 & 10.0 \\
DNA, 50 ng & 2.0 & 2.0 \\
\hline
\end{tabular}


Table 5 Primers used for PCR analysis

\begin{tabular}{llll}
\hline Title of the primer & Sequence of oligonucleotides (5'- > 3') & Site of flanking beginning & Site of flanking end \\
\hline Forvard primer AP & GCTCTCCTGGCTACTGACC & 4772 & 791 \\
Reverse primer ZM2 & CTCTGATGGCTAAGGGCAGACACGGC & 5822 & 848 \\
Reverse primer ZM5 & GCTAGGCCTAAGGTCAGGGCCGC & 5743 & 766 \\
\hline
\end{tabular}

HaeIII and BstYI, which were produced by the "SibEnzyme". Restriction fragments, which were used to determine the genotype of the virus (Table 1), were compared with fixed-length nucleotide sequences, which were synthesized to order in the company "SibEnzyme".

The significance of the differences was determined by the Student's criterion [49]. The error of genotype frequencies was calculated by Zhivotovsky's formula [50]. Comparison of genotype frequencies with the maximum permissible mutant allele frequency of $1 \%$ [2] was carried out using the Chi-square criterion [49]. Discriminant analysis was conducted using STATISTICA 10 software.

\section{Abbreviations}

BLV: Bovine Leukemia Virus; PCR-RFLP: Polymerase Chain Reaction-Restriction Fragment Length Polymorphism; IC: Internal control; NC: Negative control; PC: Positive control; LRT-area: Long terminal repeats -the area of the BLV genome; gp: glycoprotein; bp: Bases pair

\section{Acknowledgements}

The authors thank to directorship of Novosibirsk State Agricultural University for assistance in funding this publication. We also Express your gratitude to the management and team of specialists of the "Doroninskoe farm" (Novosibirsk region, Russia) for their help in obtaining experimental data.

\section{Declarations}

The manuscript is deposited as a preprint (https://doi.org/10.7287/peerj. preprints.27902v1 | CC BY 4.0 Open Access | rec: 15 Aug 2019, publ: 15 Aug 2019).

\section{About this supplement}

This article has been published as part of BMC Genetics Volume 21 Supplement 1, 2020: Selected Topics in "Systems Biology and Bioinformatics" - 2019: genetics. The full contents of the supplement are available online at https://bmcgenet.biomedcentral.com/articles/supplements/volume-21supplement-1.

\section{Authors' contributions}

All authors read and approved the final manuscript. NB development of methods of PCR analysis of LRT-region of BLV, development of the general scientific concept of the article, processing of primary data, statistical processing of experimental data and writing the primary text. SV solution of the organizational and technical aspects of the study. $A D$ scientific management of research, consultation on methods for, diagnosing bovine leukemia, development of the general scientific concept of the article. KSh writing the final text of the article, scientific analysis of the research results, hypothesizing the emergence of new strains of haplotype I, as well as the origin and distribution of haplotype II, preparing the manuscript for publication, working with the editor. VR, KP, AKh, SP - direct sampling of biological material, DNA isolation, PCR reactions and interpretation of its results.

\section{Funding}

This study was funded by the Ministry of agriculture of Russian Federation (№ AAAA-A20-120012290079-3). The funding body played no role in the design of the study and collection, analysis, and interpretation of data and in writing the manuscript. Publication costs have been funded by budgetary funds of Novosibirsk State Agrarian University.

\section{Availability of data and materials}

All data generated or analyzed during this study are included in this published article.

\section{Ethics approval and consent to participate}

The research was carried out in compliance with existing Russian and international regulations including Basel Declaration (https://www.baseldeclaration.org/basel-declaration/). The results of the research were reported on compliance with ethical standards for the treatment of animals at a meeting of the Ethics Committee of the Novosibirsk State Agrarian

University, where a unanimous decision was made to allow the article to be published in an international journal. The manuscript does not contain any data about individuals. The data of this articleon the physiological state of animals (cattle) are submitted for publication with the permission of the head of the Doroninskoye farm (Toguchin district, Novosibirsk region, Russia).

\section{Consent for publication}

Not applicable.

\section{Competing interests}

The authors declare no conflict of interests.

\section{Author details}

'Laboratory of Enzyme Analysis and DNA Technologies, Novosibirsk State Agricultural University, Novosibirsk, Russia. ${ }^{2}$ Laboratory of Leukemia, Institute of experimental veterinary medicine, Siberia and the Far East, Siberian Federal Research Centre for Agrobiotechnology of the Russian Academy of Sciences, Krasnoobsk, Novosibirsk region, Russia.

Published: 22 October 2020

\section{References}

1. Agol V.I. Nature of virus pathogenicity. Priroda=Nature. 2015; 5: 3-10. https://priroda.ras.ru/pdf/2015-05.pdf. (In Russian).

2. Lewin B, Genes IX. Page No.20, 36. Jones \& Bartlett Learning; 2007.

3. Markov A. The birth of complexity. Evolutionary biology today: unexpected discoveries and new questions. Page no. 13. Moscow: ACT CORPUS Publ; 2010. (In Russian).

4. Moelling K. Viruses: More Friends Than Foes. Singapore: Page No. 9. World Scientifc Publishing. 2016. doi: https://doi.org/10.1142/10230.

5. Veterinary encyclopedia. Under the General editorship of A.I. Yatusevich. Vol. 2. Belarusian encyclopedia. Page No. 205. 2013. http://www.encyclopedia.ru/ cat/books/book/23595/. (In Russian).

6. Pluta A, Rola-Łuszczak M, Kubiś P, Balov S, Moskalik R, Choudhury B, Kuźmak J. Molecular characterization of bovine leukemia virus from Moldovan dairy cattle. Arch Virol. 2017;162:1563-76. https://doi.org/10.1007/s00705-0173241-4.

7. Polat M, Takeshima S, Aida Y. Epidemiology and genetic diversity of bovine leukemia virus. Virol J. 2017;14:209. https://doi.org/10.1186/s12985-017-0876-4.

8. Gutiérrez G, Rodríguez SM, de Brogniez A, Gillet N, Golime R, Burny A, Jaworski JP, Alvarez I, Vagnoni L, Trono K, Willems L. Vaccination against $\delta$ retroviruses: the bovine leukemia virus paradigm. Viruses. 2014;6(6):2416-27. https://doi.org/10.3390/v6062416.

9. Gyles C. Should we be more concerned about bovine leukemia virus? Can Vet J. 2016;57(2):115-6 https://www.ncbi.nlm.nih.gov/pmc/articles/PMC4712 985/.

10. Juliarena MA, Barrios CN, Lützelschwab CM, Esteban EN, Gutiérrez SE. Bovine leukemia virus: current perspectives. Virus Adaptation and Treatment. 2017; 9:13-26. https://doi.org/10.2147NAAT.S113947. 
11. Buehring GC, De Laney A, Shen H, Chu DL, Razavian N, Schwartz DA, Demkovich ZR, Bates MN. Bovine leukemia virus discovered in human blood. BMC Infect Dis. 2019;19(1):297. https://doi.org/10.1186/s12879-019-3891-9.

12. Stocking C, Kozak CA. Murine endogenous retroviruses. Cell Mol Life Sci. 2008;65(21):3383-98. https://doi.org/10.1007/s00018-008-8497-0.

13. Barez PY, de Brogniez A, Carpentier A, Gazon H, Gillet N, Gutiérrez G, Hamaidia M, Jacques JR, Perike S, NeelatureSriramareddy S, Renotte N, Staumont B, Reichert M, Trono K, Willems L. Recent advances in BLV research. Viruses. 2015;7(11):6080-8. https://doi.org/10.3390/v7112929.

14. Florins A, Gillet N, Asquith B, Boxus M, Burteau C, Twizere JC, Urbain P, Vandermeers F, Debaca C, Sanchez-Alcaraz MT, Schwartz-Cornil I, Kerkhofs P, Jean G, Théwis A, Hay J, Mortreux F, Wattel E, Reichert M, Burny A, Kettmann R, Bangham C, Willems L. Cell dynamics and immune response to BLV infection: a unifying model. Front Biosci. 2007;12:1520-31. https://doi. org/10.2741/2165.

15. Sagata N, Suzuku-Kawamura T, Nagayoshi-Aida M, Shimizu F, Imagawa K, Ikawa Y. Identification and some biochemical properties of the major XBL gene product of bovine leukemia virus. Proc Nati Acad SciUSA. 1985;82: 7879-83. https://doi.org/10.1073/pnas.82.23.7879.

16. UniProtKB - P51519 (ENV_BLV)[Internet].https://www.uniprot.org/uniprot/ P51519.

17. Alber G, Kim K-W, Weiser P, Riesterer C, Carsetti R, Reth M. Molecular mimicry of the antigen receptor signalling motif by transmembrane proteins of the Epstein-Barr virus and the bovine leukaemia virus. Curr Biol. 1993;3:333-9. https://doi.org/10.1016/0960-9822(93)90196-u.

18. Rice NR, Stephens RM, Couez D, Deschamps J, Kettmann R, Burny A, Gilden $\mathrm{RV}$. The nucleotide sequence of the env gene and post-env region of bovine leukemia virus. Virology. 1984;38:82-93. https://doi.org/10.1016/00426822(84)90149-1.

19. Reichert M, Winnicka A, Willems L, Kettmann R, Cantor GH. Role of the Proline-Rich Motif of Bovine Leukemia Virus Transmembrane Protein gp30 in Viral Load and Pathogenicity in Sheep. J Virol. 2001;75(17):8082-9. https:// doi.org/10.1128/JVI.75.17.8082-8089.2001.

20. Johnston ER, Albritton LM, Radke K. Envelope Proteins Containing Single Amino Acid Substitutions Support a Structural Model of the ReceptorBinding Domain of Bovine Leukemia Virus Surface Protein. J Virol. 2002; 76(21):10861-72. https://doi.org/10.1128/JVl.76.21.10861-10872.2002.

21. Bateneva NV. Of course leukemic process in media 4 and 7 genotypes BLV. Innovatsii I prodovolstvennaya bezopasnost = Innovations and Food Safety. 2015;4(10):5-8 (In Russian) https://elibrary.ru/item.asp?id=25934571.

22. Dequedt F, Kettmann R, Burny A, Willems L. Mutations in the p53 tumorsupperior gene are frequently associated with bovine leukemia virusincluced leukemogenesis in cattle but not in sheep. Virology. 1995;209:67683. https://doi.org/10.1006/viro.1995.1303.

23. Florins $A$, de Brogniez $A$, Elemans $M$, Bouzar $A-B$, François $C$, Reichert $M$, Asquith $B$, Willems $L$. Viral expression directs the fate of $B$ cells in bovine LeukemiaVirus-infected sheep. J Virol. 2012;86(1):621-4. https://doi.org/10. 1128/JVI.05718-11.

24. Marawan MA, Mekata H, Hayashi T, Sekiguchi S, Kirino Y, Honri A-M Moustafa M, Arnaout FK, Galila ESM, Norimine J. Phylogenetic analysis of env gene of bovine leukemia virus strains spread in Miyazaki prefecture, Japan. J Vet Med Sci. 2017;79(5):912-6. https://doi.org/10.1292/jvms.17-0055.

25. Rodriguez SM, Golemba MD, Campos RH, Trono K, Jones LR. Bovine leukemia virus can be classified into seven genotypes: evidence for the existence of two novel clades. J Gen Virol. 2009;90:2788-97. https://doi.org/ 10.1099/vir.0.011791-0

26. Smirnov PN, Bateneva NV. Virus-genetic aspects of bovine leukemia virus (BVL). Dostizhenia nauki I tekhniki v APK = Achievements of science and technology of agriculture. 2012;4:71-2 (In Russian) https://elibrary.ru/item. asp?id=17109100.

27. Blazhko NV, Vyshegurov SKH, Donchenko AS, Shatokhin KS, Krytsyna TI, Ryabinina VA. Association of haplotypes for SNPs in the LTR regions of bovine leukemia virus with hematological indices of cattle. Vavilov I Genet Breed. 2019;23(3):162-9. https://doi.org/10.18699/NJ19.491.

28. Gendzhiyeva OB. Phylogenetic comparison of the virus of leukosis of cattle. Vestnik Kalmytskogo Universiteta= Bulletin of Kalmyk University. 2012;2(14): 10-6 (In Russian) https://cyberleninka.ru/article/n/filogeneticheskoesravnenie-virusa-leykoza-krupnogo-rogatogo-skota-1.

29. Bateneva NV, Smirnov PN, Mikhnovich IV, Isakova MB. Analisis of the distribution of genotypes BLV (ENV, GP51) in Novosibirsk and Krasnodar regions. Agrarnyi vestnik Urala= Agrarian Bulletin of the Urals. 2011;9(88):6 (In Russian). https://elibrary.ru/item.asp?id=17849953.

30. Behavides B, Muñoz S, Ceriani C. Molecular analysis of a fragment of bovine leukemia virus env gene by Nested-PCR in dairy cows from Pasto, Nariño. Rev. Med. Vet. 2017;33:67-75. https://doi.org/10.19052/mv.4054.

31. Heenemann K, Lapp S, Teifke JP, Fichtner D, Mettenleiter TC, Vahlenkamp TW. Development of a bovine leukemia virus polymerase gene-based realtime polymerase chain reaction and comparison with an envelope genebased assay. J Vet Diagn Investig. 2014;24(4):649-55. https://doi.org/10.1177/ $1040638712447524 \mathrm{http} / / / j v d i . s a g e p u b . c o m$.

32. Lee EJ, Kim E-J, Joung H-K, Kim B-H, Song J-Y, Cho I-S, Lee K-K, Shin Y-K. Sequencing and phylogenetic analysis of the gp51 gene from Korean bovine leukemia virus isolates. Virol J. 2015;12:64. https://doi.org/10.1186/ s12985-015-0286-4.

33. Rola-Łuszczak M, Pluta A, Olech M, Donnik I, Petropavlovskiy M, Gerilovych A, Vinogradova I, Choudhury B, Kuźmak J. The Molecular Characterization of Bovine Leukaemia Virus Isolates from Eastern Europe and Siberia and Its Impact on Phylogeny. PLoS ONE. 2013;8(3):e58705. https://doi.org/10.1371/ journal.pone.0058705.

34. Yang Y, Kelly PJ, Bai J, Zhang R, Wang C. First molecular characterization of bovine leukemia virus infections in the Caribbean. PLoS One. 2016;11(12): e0168379. https://doi.org/10.1371/journal.pone.0168379.

35. Black-and-White cattle in Sibiria. Zheltikov A.l. et al. Ed. Page No. 10. "Prometei" Novosibirsk. 2010. (In Russian).

36. Durov AS, Deyeva VS, Gamarnik NG. Description of genealogical lines of black-pied cows. Vestnik alraiskogo agrarnogo universiteta= Bulletin of Altai state agricultural university. 2014;8(118):78-81 (In Russian). https://elibrary.ru/ item.asp?id=21968152

37. Klimenok II, Yaranceva SB, Shishkina MA. Produktive and breeding qualities of black and motley cattle Siberian region. Guenetika I razvedenie zhivotnykh = Genetic and breeding of animals. 2014;2:30-3 (In Russian). https://elibrary.ru/item.asp?id=24353813.

38. Picoli T., Zani J.L., Cristina Mendes Peter C.M., Victor Fernando Büttow Roll V. F.B., Ribeiro M.E.R., D'Ávila Vargas G., Oliveira Hübner S., de Lima M., Fischer G. Milk production characteristics in Southern Brazil. Semina: Ciências Agrárias, Londrina. 2015; 36(3): 1991-1998. doi: https://doi.org/10.5433/16790359.2015v36n3Supl1 p1991.

39. Lojkić I, Balić D, Rudan N, Kovačić M, Čač Z, Periškić M, Bedeković T, Roić B, CiglarGrozdanić I. Eradication of bovine leukosis virus on a diary farm through improved virus detection. Veterinarski arhiv. 2013;83(6):581-91 https://scholar.google.com/scholar_lookup?title=\&journal=Vet.\%20Arch. \&volume=83\&publication_year=2013\&author=Lojki\%C4\%87\%2Cl.\&author= Bali\%C4\%87\%2CD.\&author=Rudan\%2CN.\&author=Kova\%C4\%8Di\%C4\%87\%2 CM.A.\&author=\%C4\%8Ca\%C4\%8D\%2C\&author=Peri\%C5\%A 1 ki\%C4\%87\%2 CM.\&author=Bedekovi\%C4\%87\%2CT.\&author=Roi\%C4\%87\%2CB.\&author= Grozdani\%C4\%87\%2Cl.

40. Barrick JE, Yu DS, Yoon SH, Jeong H, Oh TK, Schneider D, Lenski RE, Kim JF. Genome evolution and adaptation in a long-term experiment with Escherichia coli. Nature. 2009:461(7268):1243-7. https://doi.org/10.1038/ nature08480.

41. Gomez-Uchida D, Seeb JE, Habicht C, Seeb LW. Allele frequency stability in large, wild exploited populations over multiple generations: insights from Alaska sockeye salmon (Oncorhynchus nerka). Can J Fish Aquat Sci. 2012;69: 916-29. https://doi.org/10.1139/F2012-029.

42. Guerrero RF, Hahn MW. Speciation as a sieve for an cestra polymorphism. Mol Ecol. 2017;20:5362-8. https://doi.org/10.1111/mec.14290.

43. Nikitin SV, Knyazev SP. Selection and adaptation in domestic pig populations. Saarbrucken: Lambert Academy Publ; 2015. (In Russian).

44. Nikitin SV, Knyazev SP, Shatokhin KS. Miniature pigs of ICG as a model object for morphogenetic research. Russ J Genet: Appl Res. 2014;4(6):51122. https://doi.org/10.1134/S207905971406015X.

45. Fitzsimmons WJ, Woods RJ, McCrone JT, Woodman A, Arnold JJ, Yennawar M, Evans R, Cameron CE, Lauring AS. A speed-fidelity trade-off determines the mutation rate and virulence of an RNA virus. PLoS Biol. 2018;16(6): e2006459. https://doi.org/10.1371/journal.pbio.2006459.

46. Korboukh VK, Lee CA, Acevedo A, Vignuzzi M, Xiao Y, Arnold JJ, Hemperly S, Graci JD, August A, Andino R, Cameron CE. RNA Virus Population Diversity, an Optimum for Maximal Fitness and Virulence. J Biol Chem. 2014:289(43): 29531-44. https://doi.org/10.1074/jbc.M114.592303.

47. Markov A, Naimark E. Evolution. Classical ideas in the light of new discoveries. Page no. 38. Moscow: ACT CORPUS Publ; 2015. (In Russian). 
48. Principles and Techniques of Biochemistry and Molecular Biology. Edited by K. Wilson and J. Walker. Sixth edition. Page No. 498. Copyright Cambridge University Press. 2005. https://doi.org/10.1017/CBO9780511813412.

49. Lakin G.F. Biometrics. Page No. 319. M.: Vysshaya shkola Publ. 1990. (In Russian) https://mf.bmstu.ru/info/faculty/lt/caf/tt1/soil_books/uchebnik10.pdf.

50. Zhivotovskiy L.A. Populational biometry. Page No. 41. M.: Nauka. 1991. (In Russian).

\section{Publisher's Note}

Springer Nature remains neutral with regard to jurisdictional claims in published maps and institutional affiliations.

Ready to submit your research? Choose BMC and benefit from:

- fast, convenient online submission

- thorough peer review by experienced researchers in your field

- rapid publication on acceptance

- support for research data, including large and complex data types

- gold Open Access which fosters wider collaboration and increased citations

- maximum visibility for your research: over $100 \mathrm{M}$ website views per year

At $\mathrm{BMC}$, research is always in progress.

Learn more biomedcentral.com/submissions 